\section{Revista de la \\ Universidad del Thulia}

Fundada en 1947 por el Dr. Jesúns Enrique Lossada

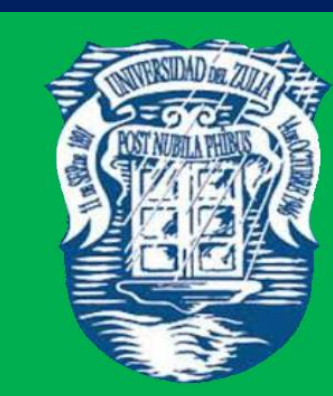

Ciencias del

Algreo

Ingemieria

y Teemología

\section{Aกัต 11 No 29}

Enero - Abril 2021

Tercera Época

Maracaibo-Venezuela 


\title{
Recognition of architectural patterns in the houses of the Niakie neighborhood in Amol
}

\author{
Zohreh Sanaei* \\ Jamshid Mirhadi** \\ Ali Asgharzadeh***
}

\begin{abstract}
Traditional housing fabrics are an obviously valuable heritage to be reviewed and analyzed, as they present the right pattern for native architecture because it is considered the main core in the creation of cities, as well as the architectural elements and buildings located in them. The objective of this study is to review and recognize the physical and social behavior patterns of these buildings to improve these valuable fabrics and save them from their presence of unusual buildings. First, this study would review the key problems on the design of patterns in the architecture of the house, obtaining an analytical-descriptive point of view; This research first reviews the key issues of the patterns in the architecture of the house, and then identifies the physical components that are effective in traditional buildings, contrasting with the theoretical foundations obtained. The next step has been the identification and physical review using the field research method to physically identify and review the case study buildings in the historical fabric. After the analysis, the most effective physical components would be prioritized by hierarchical method. Finally, considering the results obtained, not only the principles of native architecture are identified, but also some approaches are introduced to improve the relationship between physical behavior environments in the Niakie neighborhood in Amol.
\end{abstract}

KEY WORDS: Behavior pattern, recognition of traditional fabric, native residential home, Niakie neighborhood in Amol.

*PHD student of Architecture, Nour Branch, Islamic Azad University, Nour, Iran, zohrehsanaei.architect@gmail.com

**Professor of Architecture, Nour Branch, Islamic Azad University, Nour, Iran, jamshid.mirhadi@gmail.com

${ }^{* * *}$ Assistant professor of Architecture, Chalous Branch, Islamic Azad University, Chalous, Iran, ali.asgharzadeh@iauc.ac.ir 


\section{Reconocimiento de patrones arquitectónicos en las casas del vecindario de Niakie en Amol}

RESUMEN

Los tejidos de vivienda tradicionales son un patrimonio obviamente valioso para ser revisado y analizado, pues presentan el patrón adecuado para la arquitectura nativa porque se considera el núcleo principal en la creación de ciudades, así como los elementos arquitectónicos y los edificios ubicados en ellas. El objetivo de este estudio es revisar y reconocer los patrones de comportamiento físico y sociales de estos edificios para mejorar estos valiosos tejidos y salvarlos de su presencia de edificios inusuales. Primero, este estudio revisaría los problemas clave sobre el diseño de patrones en la arquitectura de la casa, obteniendo un punto de vista analítico-descriptivo; esta investigación primero revisa los temas clave de los patrones en la arquitectura de la casa, y luego identifica los componentes físicos que son efectivos en edificios tradicionales, contrastando con los fundamentos teóricos obtenidos. El siguiente paso ha sido la identificación y revisión física mediante el método de investigación de campo para identificar y revisar físicamente los edificios de estudio de caso en el tejido histórico. Después del análisis, los componentes físicos más efectivos serían priorizados por método jerárquico. Por último, considerando los resultados obtenidos, no solo se identifican los principios de la arquitectura nativa, sino que también se introducen algunos enfoques para mejorar la relación entre los entornos de comportamiento físico en el vecindario de Niakie en Amol.

PALABRAS CLAVE: Patrón de comportamiento, reconocimiento de tejido tradicional, hogar residencial nativo, vecindario de Niakie en Amol.

\section{Introduction}

In one hand, home has such an importance in setting down, relaxing, selfreferring, growth and human movement. On the other hand, these are mess, vast and non-identical spaces in today's life. So, there should be thinking and meditating about this issue. These days, from the quantity point of view, the housing usage has been mostly specialized to the urban buildings including the historical_traditional tissues. The space border and spritlessness is usually because of lack in types of fixed behavioral patterns in the environment. The most important point is the need to get the balance, make the matching and adjustment of a behavioral pattern with its physical environment, in which the behavior occurs. This feature causes for some places to be in 
more suitable relationship with some behavioral patterns and have more capability (Rivas, 2018). Among these, Amol is one of the historical cities of Iran in which there are some valuable and architectural houses in its traditional tissue. The target of this study is to review and recognize the behavioral and social patterns of these buildings to improve these valuable tissues and to save them against her presence of unusual buildings. The planner has relied on the her context knowledge from presented buildings patterns, urban patterns and other environmental patterns to get a theory about the behavioral patterns, This matter can predict about the future environmental. This paper is considered descriptive analytic according to the method and one of the partical researches according to the target. The question that is answered at the end of the study are the patterns of physical behavior, the most important in Amol. Historical traditional housing spaces, " Niakie neighborhood ": so, in addition to knowing the related concepts, selecting the method and suitable analysis, at the end of the research, there would be some solutions to connect the behavior and physical environment around Niakie neighborhood.

\section{Research Background}

\section{1.l. Pattern}

Pattern does not judge about the special ideas, targets or values. The pattern result can let the things be alive and this is much better than conquering every artificial valued systems. To define all the existing forces is the only way in which the pattern can practically help to make a situation live honestly. Then the world would be found in witch the forces can get far from each other, the pattern gets a part of the nature and finally, when we can deeply look at the pattern which is made by human, so deeply without any shadow of idea and image, we have found a part of the nature which has the same validity and eternity (Alexander, 2011).

Norman has been applied a significant change in Gibson's theory. He has substituted the expression of conceptual capability instead of view capability instead of view capability because according to him, the designers care about what is done by user understanding more than something which has the possibility of correctness. 
Considering this issue, knowing the concept of capability is followed to make it clearer in building a theoretical farm to define a theoretical investment to form it in a paternal method.

\section{1.l.1. The definition of behavioral pattern}

Behavior is the most observable and human reaction to the environment where he is situated in. so, the person can issue a message or contact with the others only by showing their behaviors in the environment without using any word but by using the behavior identity as a nonverbal tool. The way of doing any activity is behavior. The human behavior is the process of human's motivation and demands, the environment capability, the person's mental image from the utter world causing from his understanding and the meaning of image for him. Although the behavior is touchable and definite, it has a kind of complicated mechanism. Environmental behavior predication is the one of the main questions for behaviorists for which it makes many years study to find the answer for the behavioral experts. Even, some researchers introduce the behavioral science as the beginning of environmental psychology (Shahcheraghi \& Bandarabad, 2015).

On the other hand, Alexander says that a building prides itself quietly and gracefully based on the panguage effect of common patterns which makes it and every presented part and activity which has leaded it. All the huge buildings in the history are built like this; by languages. So a rich pattern is a collection of patterns adjusted to the deep consideration about what ever makes a building more beautiful. According to Etelson, the information coming from the environment has symbolic and meaningful features; they have traits which present the mental reactions and have messages which motivate the demands. The values and aesthetical properties are transferred to the environment by people because human being needs to experience the environment as a model from meaningful relationships.

The previous experiences are the base of to understand the new condition. According to the studies of the reaction approaches, people describe their understanding both in an experienced from and in a structural type. 


\subsubsection{Designing the behavior pattern}

The process of environment adjustment with behavior pattern include the physical environment designing would be defined by behavior patterns they need. Maybe, experts who have the related fields to designing can also define these objectives. These experts including the time and movement researchers, the ease planners or the people like these, know both activity systems and the manner of effect on the built environment on behavior. This process is formed more imaginatively and it is usually due at the time of decision making on spaces unconsciously (Alexander, 2011).

As Shahrokhabadiet et al, have written; the spaces names can show the activities which one done in them. The architects and planners use the more improved technologies of behavioral sciences to make the process easy be more objective of course the patterns and different in every culture and in every period. However, all of them are all man-made and dependent to the culture. In every period and everywhere, the structure of our world is necessarily the result of the patterns collections which are repeated (Shahrokhabadiet al., 2019).

John Lang (2002) believed that the designing process cannot be totally scientific, any way but it can be describe and explained by using the scientific and semi scientific methods. The abilities of the specific patterns for the made environment can be achieved by its designing manner, the materials used in it and its installation way results from the special group of people. In the known meaning levels (such as understanding), defining the environment abilities seems to be a performance from the human's biological features and on the symbolic meaning level, these abilities are performance of people's culture and social experience (Lang, 2002).

According to Maier and Fadel, then should be a kind of ability before a capable ability can occur (Maier \& Fadel, 2009).

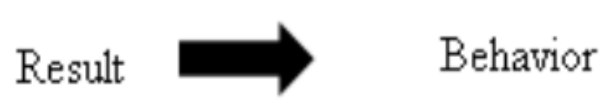

Situation (environment)
Character (insidious factors)

Figure 1. A diagram of human's behavior 
Attention to human behavior and its role in the environment have been brought into the realm of behavioral geography using psychological thought and theories. The spatial behavior of the people is almost affected by the mental images from the environmental structure and can impact a lot on people's direction finding through the buildings, neighborhoods and cities.

\subsection{Architectural ancient pattern experiences}

The city surrounding tissue has various buildings falling images. As well as wide's pread trench like spaces full of sleeping cats. This mentioned city tissue has been surprisingly situated against its pure and empty interior. The city complete silence made by light and darkness wrapped may in arms by abstract of the interior and exterior. These ancient pattern experiences are neither the sensational facing nor severely logical and scientific but the pure 3 and 4-dimensional concepts. Perception considering the concept is like a model for architectural thinking in which every architectural student tries to be an observer. The art of observing is especially enjoyable because it is involved with the world's discovery. However, it remains in a perspective through which we from our paternal views (Holl et al., 2006).

1.3 The identical features of a traditional neighborhood according to the recognizing occurrence

\subsubsection{Recognition}

Atkinson (2005) says, defining the nature of the gained information is the first thing that our conceptual system should do to make the information meaningful. As a matter of fact, recognizing something is relating it to an issue. There are a lot of things to help us to recognize things but the shape is the most important factor. The shape importance in recognition is because of this fact that we can recognize a lot of objects by seeing the general line and the simple line patterns in which only the objects shape is remained safe and it is true even when they are black and white or they are not situated in a situation as they are always in.

\subsubsection{Recognition of the traditional tissues}


The traditional tissue is the synthesis of all physical parts and general organic streets and blocks that can be known as different manners of neighboring, the full and empty spaces in various combinations as well as segmentation of the specific lands. The features related to the neighborhood recognition field are the basic feature which is the infra-structure to the occurrence of a local system these features are reviewed based on 3 analytical orientations in traditional neighborhood.

- Boarding the neighborhood socially and culturally

- The hierarchical spatial and performing system

- Following the scale, unity and coordination in

- Physical tissue and appearance, in neighborhood center and the neighborhood services (Falamaki, 2015).

\subsection{The behavioral patterns in an Iranian house}

\subsubsection{The traditional houses in Iranian architecture}

The traditional houses in Iran show the living methods and the people's thought in different ages. The spatial types of these houses are defined based on the existence or lake of the physical components. The opened spaces are occurred by defining the floor and wall. The semi opened spaces are distinguished by the concept of floor, ceiling and a specific definition of wall, although the closed spaces completely present all 3 element of floor, ceiling and wall.

The constructors of these native units have tried to make the living spaces more human through making a friendly connection among living environment culture and the architectural forms (Falamaki, 2015).

\subsubsection{The house privacy}

A house is not only the person's identification reflex ion and base but also the family one. The house is the mysterious carriage of a private life hidden from the public, even though it forms the social life. The house describes the private and public limits of life (Palasma, 1992).

Rappaport knows the houses as an organization which is more than a materialistic concept through complicated targets and their performance. According 
to Moore, the house is the center of universe for its residents and for its neighborhood the most prominent building in the place standing. Both Rappaport and Palasma (1992) believe the house is the first grade of every organization which is existed for a lot complicated targets not a structure (Palasma, 1992).

\subsubsection{Changing in architectural patterns in recent houses}

In the past the housing space followed kinds of geometrical rules. However, it is now affected by the land geometry.

Also there is the change from the multipurpose spaces, multipurpose combination including the opened spaced, closed spaces and semi-opened spaces which caused the spatial variety to the recent closed living spaces.

According to Lang, one of the main targets of the recognition stage is to edit the patterns need for environment to response to the psychological and aesthetic demand. This stage cannot be forceful. Maybe the modern architect has made more mistakes in this issue rather than any other matters. It seems these architects have predicted wrongly about the behavioral patterns and the made environment ability to make specific behaviors. This revolution architects have decided based on the incomplete models of human and the human's behaviors (Lang, 2002).

\subsection{Reviewing the case studies done}

Christopher Alexander and Donald Iliyard have performed the role of behavioral patterns in forming the human oriented urban spaces. They have considered the human demands and motivations in forming the spaces in recent years and both of them have confirmed the progressive actional and behavioral patterns in spaces some of most important issues favorable for both of them are considering the micro spaces and defining the space based on the human activities the relationship between the micro spaces and macro spaces (Sadeghzadeh \& Pourmohammadi, 2013).

The analysis of socialization in physical environment comes from the nature understanding in human made environment as well as the nature understanding manner in human made environment which have meaningful effects on patterns socialization and physical spaces. 
This study has reviewed the behavioral science theorist emphasis on studying the life routine spaces in residential samples (Daneshgar Moghaddam et al., 2011).

Environment perception (the role of psychological relativism in understanding the environment) works on analyzing the rules and laws of getting the better environmental designs and patterns according to the people (Barati \& Soleimannejad, 2011)

The architectural teaching models are based on Gibbon's theory of environmental capability which has reviewed the theories and the approaches related to it. They also have defined the hidden and evident angles of the capabilities, have found the theoretical structures coming from the behavioral ideas to improve the teaching method for architectural designing and have made the practical frames in the field of architectural teaching method (Naghdbishi et al., 2019).

There is recognizing the behavioral patterns in Enghelab square in Isfahan as well as reviewing the settlements and behavioral patterns in considering environment which has done by field observations. There is also the solution presented to improve the relationship between the behavior and physical environment (Delaket al., 2017).

As a consequence, the study background has got by reviewing the researches and studies. The patterns assessment, the physical factors recognition, the behavioral pattern recognition, architecture teaching model's based on Gibson's environmental capabilities, assessment for the impact of the environmental quality components on behavioral patterns, the behavioral patterns role on forming the urban, human oriented spaces according to Christopher Alexander and Donald Epilard and reviewing the theoretical foundations has been resulted through library studies. This history has helped a lot to cognitional analysis of behavioral pattern in historical houses in Niakie neighborhood. So, we in reviewed the patterns and their results (Latifi \& Sajjadzadeh, 2015).

\section{Study Methodology}

To describe the methodology and gained results, in this study, firstly the research basic recognition has been done by analytical discretional methods and field studies the 
required and basic information has been gathered. Also, according to the research approach based on physical components, the main related methods to the study title, the tables considering them, physical components and pattern recognition would be reviewed. The pattern elefinition in the previous architecture can help us in the modern designing especially in housing architecture. So, in this research, the pattern recognition has selected viewing the theoretical foundations, field studies as well as considering the physical view and practical approaches to the new diagrams. According to the mentioned principles, in this pattern recognition; some components are reviewed. These components include: the sectors tissues, the sectors tissue, the architectural elements, the natural elements, the architectural plans, the physical relation of the spaces, building direction in environment and the decoration pattern. There is also the architectural-physical analysis of the traditional houses in 3 spatial groups of open, semi-open and close studied in this study. The final result can be presented by the physical factors such as the space and masses system, geometry and form, spatial hierarchy, and functional system which are located in the new diagram frame to review the results.

\section{Data Analysis}

\subsection{The study region and clime}

Amol is one of Mazandaran cities. The old tissue has included 13 neighborhoods. The center is in two styles of linear and square from in Amol old tissue (Riahi, 2002). Because is located in the mild and humid region according to the climate elements, the annual temperature average is around 14.5 to 18 degree in this area and the annual temperature fluctuation is around 25 to 36 degrees (Kasmaee, 2003).

In this research, the study area is in the middle part of this historical traditional tissue called Niakie neighborhood in which there is significant building and can be reviewed as the remained art works from the ancient architecture. The architecture of Niakie houses is belonged to Qajar and Pahlavi era. Manuchehri, Malek, Darzi, Qurayshi, Ebadi and Moghimi houses are the oldest art works in this neighborhood and they are studied in this research. 


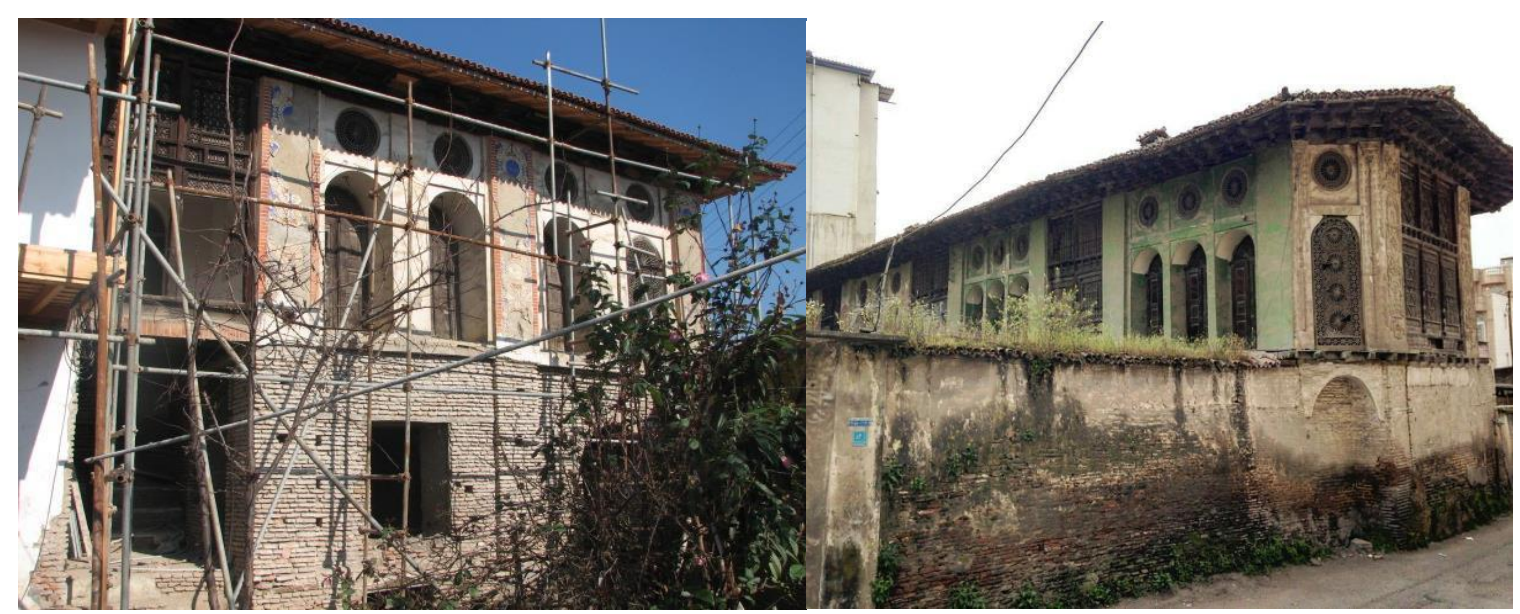

Figure 2. South view of Qureshi House

3.2. The behavioral architectural patterns about the residential case study of traditional tissue in Niakie neighborhood, Amol, Mazandaran

According to the studies done and getting information from the architectural experts and cultural heritage office, at last 7 houses have been chosen among the valuabk houses in traditional tissue of Niakie neighborhood because of the limitation to get the documentaries and past information. The houses situation map has presented in figure 1-4 and the general feature and plans are shown in table 1-2-3.

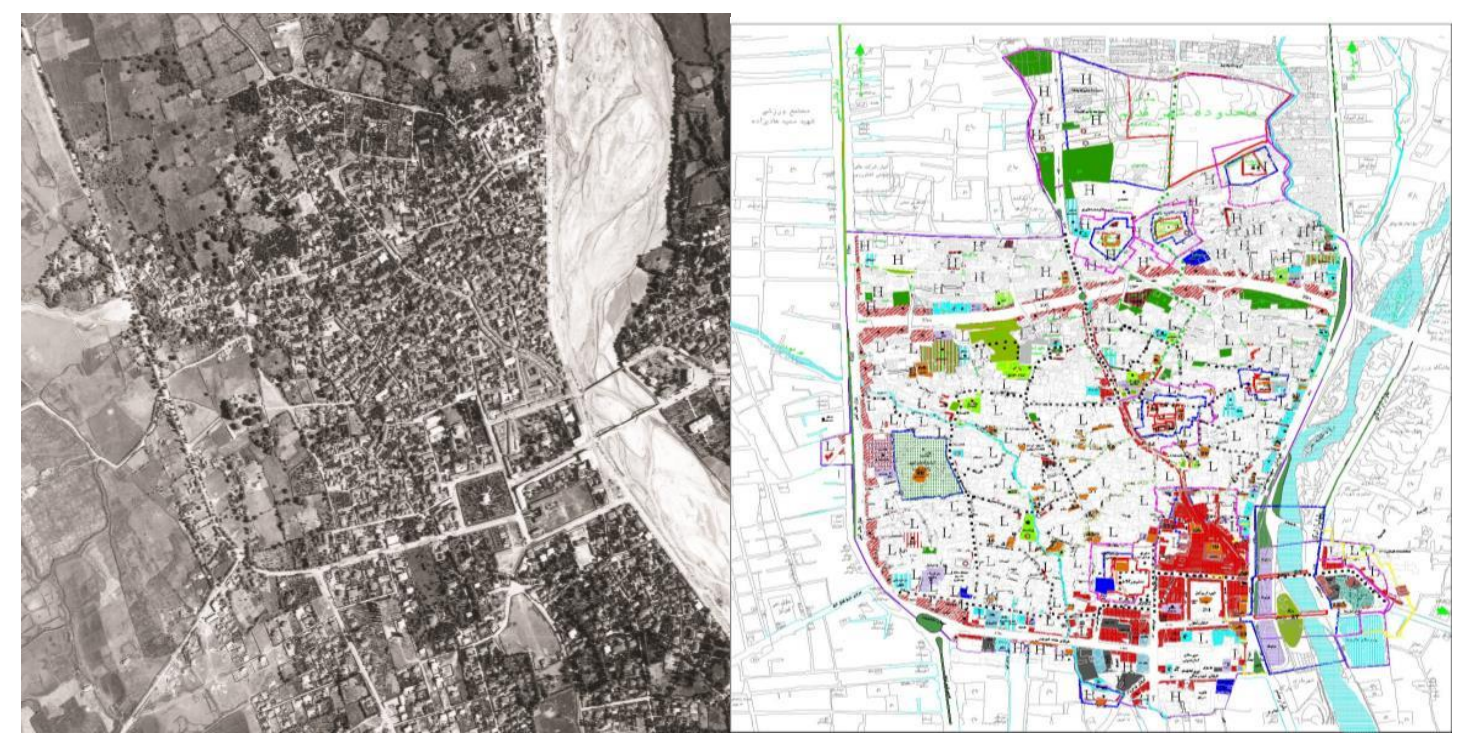

Figure 3. Aerial photo of Amol, Niaki neighborhood, 1989 
REVISTA DE LA UNIVERSIDAD DEL ZULIA. 3e época. Año 11 N² 29, 2020

Zohreh Sanaei et al. /// Recognition of architectural patterns ...173-192

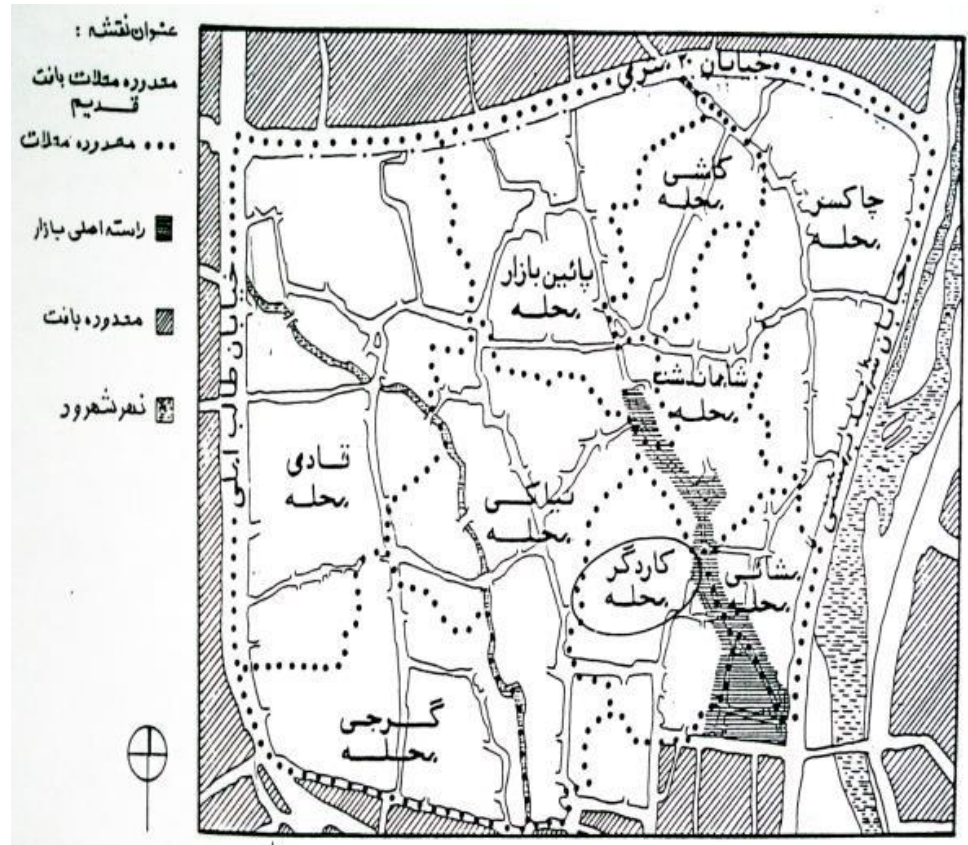

Figure 4. The general area and the neighborhood situations in the map of 50th decade about the old tissue of Amol city.

The historical tissue, accessibility, interlocking capability, the city cultural tissue, the descriptive plan sites, emptying, the view and the centralization in the city heart are really important.

The analysis of the used patterns in Mazandaran traditional houses -AmolNiakie neighborhood According to theoretical concepts of this study (behavioral pattern) and knowing the architecture, the other factors should be studies including the spaces physical connections and the building direction pattern. In this section, there is the analysis of the introducing houses as the case study.

\subsection{The spaces physical connections in houses}

The studying houses are analyzed and then because of the discussing issue in each building, the physical connectional issues in these houses are reviewed in 3 general parts based on the locating position in each space. The 3 general parts are called the open space arena, semi open and closed arena, the elongation and climatic arena. 
Table 1. The architectural definition of the selected historical houses in the traditional tissue of Niakie neighborhood, Amol

\begin{tabular}{|c|c|c|c|c|}
\hline Raw & Name & Architectural features & Photo & $\begin{array}{c}\text { Architectural } \\
\text { plan }\end{array}$ \\
\hline 1 & Manuchehri & $\begin{array}{l}\text { Inchiding entrance yard and 2- } \\
\text { story, summerhouse with one } \\
\text { entrance balcony and an } \\
\text { interconnecting space porch, } \\
\text { Extension: west to east }\end{array}$ & & \\
\hline 2 & Malek & $\begin{array}{l}\text { Inchuding entrance yard and 2- } \\
\text { story, an interconnecting space } \\
\text { porch, Extension: west to east }\end{array}$ & & \\
\hline 3 & Datzi & $\begin{array}{l}\text { Inchuding entrance yard and 2- } \\
\text { story, summerhouse with } 4 \\
\text { entrances between space porch } \\
\text { with interconnecting space to the } \\
\text { other rooms, Extension: west to } \\
\text { east }\end{array}$ & & \\
\hline 4 & Qureyshi & $\begin{array}{l}\text { Inchiding entrance yard and 2- } \\
\text { story, summerhouse with one } \\
\text { entrance balcony and an } \\
\text { interconnecting space called } \\
\text { porch, Extension: west to east }\end{array}$ & & \\
\hline 5 & Shafahi & $\begin{array}{l}\text { Inchding entrance yard and 2- } \\
\text { story, summerhouse with } 2 \\
\text { rooms which balcony of one is } \\
\text { the entrance to the other one, } \\
\text { Extension: west to east }\end{array}$ & & \\
\hline 6 & Ebadi & $\begin{array}{l}\text { Inchuding entrance yard and 2- } \\
\text { story, summerhouse with the } \\
\text { building ending into a porch } \\
\text { which is the entrance for the } \\
\text { other } 2 \text { rooms, Extension: west } \\
\text { to east }\end{array}$ & & \\
\hline 7 & Moghimi & $\begin{array}{c}\text { Inchuding entrance yard and 2- } \\
\text { story, there is one room with } \\
\text { balcony with } 3 \text { entrances and a } \\
\text { central core, Extension: west to } \\
\text { east }\end{array}$ & & 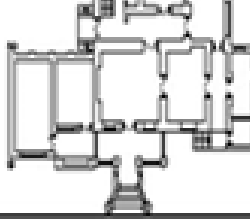 \\
\hline
\end{tabular}


Table 2. The priority pattern and physical connectional issues is houses space (practical spaces and stores connections)

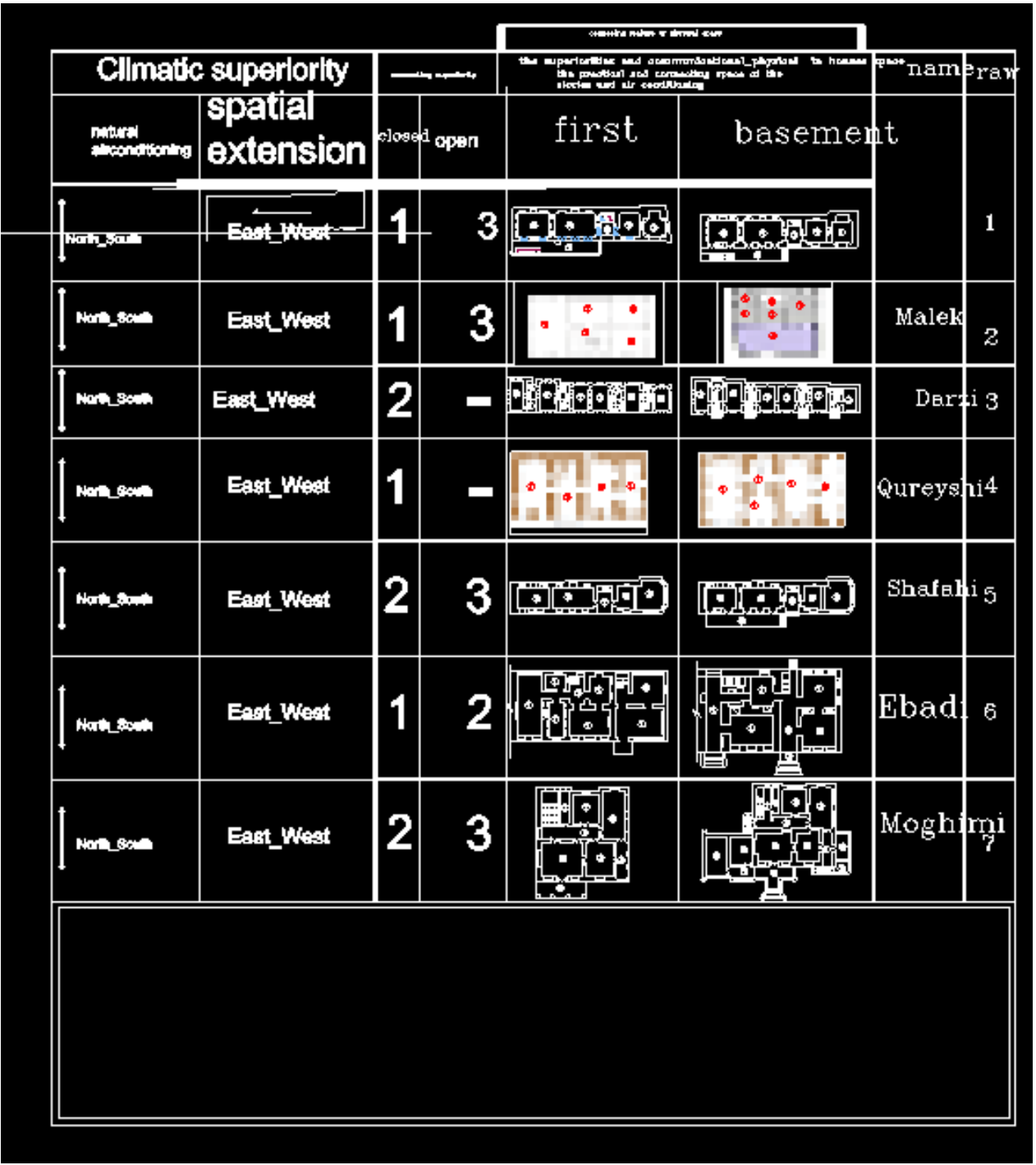

\subsection{The testing process and the final patterns, analysis}

In this part, the pattern recognition is reviewed in physical factors and would be tested through diagram drawing. Then finally the most effective physical featured would be selected based on the theoretical components, reviewing the subject history, getting the combined space patterns, getting the unity of a mixing pattern and combining the space orients. Then according to plans and architecture recognition, the line chart would be drawn for houses in Niakie neighborhood. 
In this study, the private and half private spaces, permeability and their depth are reviewed in table 4 . As a consequence, the spaces which would be in the less depth then entering spaces have optimum function and in this case, the spatial orbiting can be done more suitably and finally it promotes the function efficiency.

Conjunction: It means joining or separating of that space to the other existing spaces on that configuration and its concept is related to the depth that means the conjunct space is the one that the other environmental spaces are situated in rather lower depth than that. It has also direct and linear relationship to the connection index.

Access and connection: It is detected by space syntax technique from the perspective of visual and physical access. Also, connection is the connection among the links which are made between every space with the other space. Generally, functional performance indicators are calculated like the below table considering the previous contents.

Functional performance indicators the accessibility

The accessibility

Depth

Conjunction

Connection

To review and recognize the components and functional performance indicators is for making house desirability as well as assessment and reviewing the vestibule role and its influence on this spatial desirability of considered houses in old tissue of Niakie neighborhood. Based on the introducing the functional performance indicators and reviewing their role on vestibule in this physical spatial system, ever central closed space is not considered as the vestibule pattern. Vestibule means after passing the house head, we step to a space with the pausing possibility which is dimmer and colder than the trance and has gifted a kind of welcoming and relaxing manner to the user but from value point of view and national norms (hospital and respect to the person's understanding from the environment), around the vestibule can be mentioned to make a suitable space from the guests to relax and wait and it also has the socialization and conjunction and people's gathering ability or at least the family gathering situation is included. The getting survey from these houses residents has proved this matter totally. 
Table 4. Providing solutions related to extracted patterns influenced by physical structure and spatial behavior

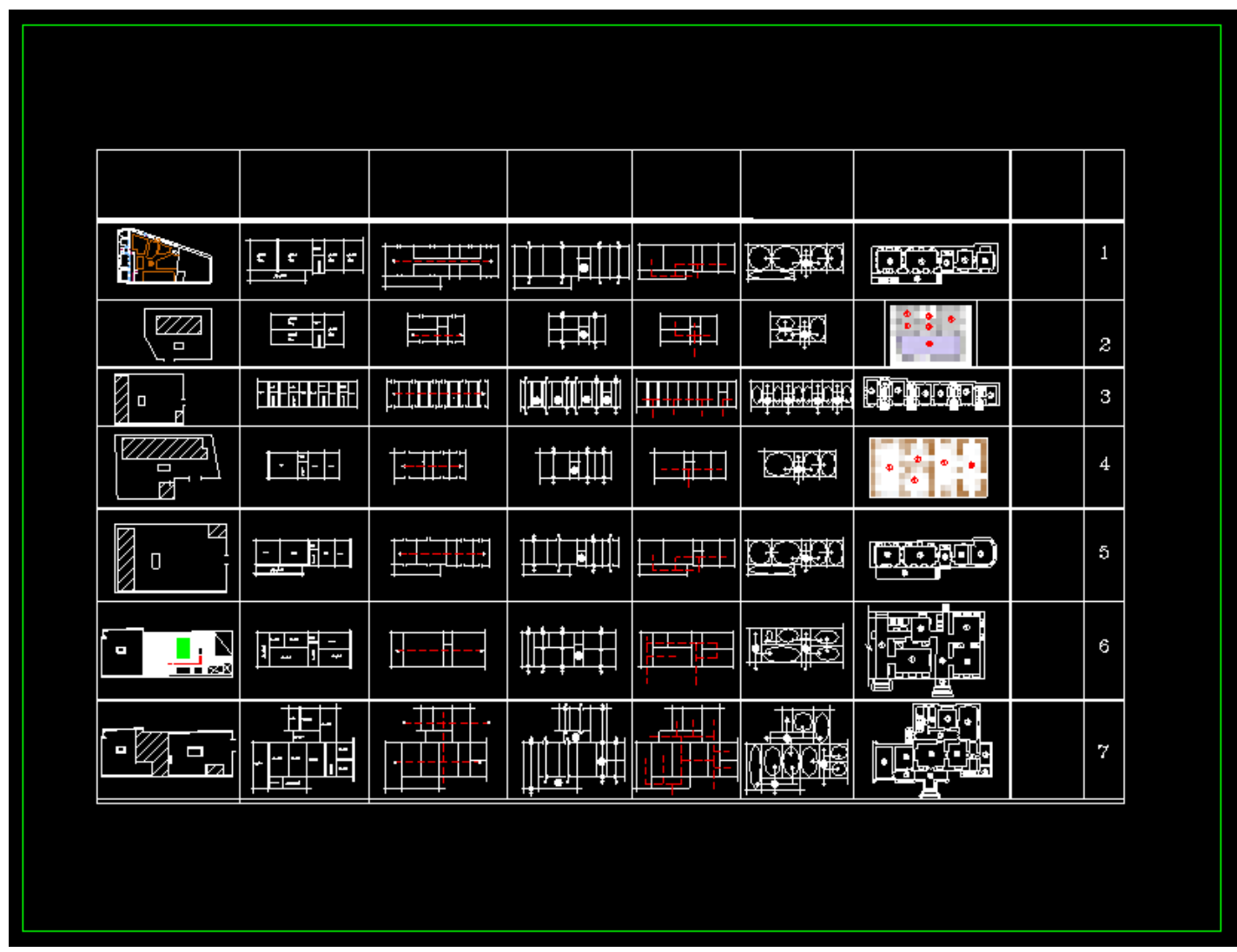

Conclusion and Presenting the Solution

Recognition of the traditional tissue is to get the past identity maker native patterns and using it in today's architecture. So, according to the environment understanding, editing the environmental patterns is needed to answer the re-cognitive activities and requirements. The results show that the extroversion and interpose patterns in houses of Niakie neighborhood in Amol have Eastern-western elongation interest on the other hand, it can be shown by comparing the factors matching with the architectural features, mess and spaces, functional connection and building direction can be the priority of the house forming to get the continues behavioral pattern in the modern designing.

In order to continue the identity and modern building and structure to be united with the historical issue of Niakie neighborhood in Amol as well as using the 
conclusions coming from research, there would be suitable solution to review the spatial and physical patterns which are presented by analyzing the archived diagrams in order to make the harmony with the traditional tissue using the traditional architectural components. We can use the archived diagrams in their updated from to present in today's building in Niakie neighborhood because they follow all the climate and situational factors. In Mazandaran climate, the houses are both extrovert and introvert. There are balcony and yard in all Mazandaran houses which is extroversion indicator and dividing space or vestibule and the connecting hall for rooms and space are introspection indicators. It is important to combine the spaces and their function in mild climate. By space recognition, a modern pattern will be achieved with the same function. So, a case with cultural pattern (hidden biological pattern) should be solved before considering the relationship between the values of space decoration and function in buildings and structures. This issue can be used as s designing pattern in the future.

The research results prove the correctness of research patterns recognition. So, the people's spatial behaviors can be more positively assessed if the physical environment includes suitable and adjusted organizing to the need of clients considering the effects of environmental making elements and the physical structures on people's spatial behaviors based on psychological, personal, identical, cultural and climatically features, people's social life and the way of their living. These things should have the ability of accessibility. After the analysis which is done, it is tried to present an effective design based on the psychological features and getting the people's sati's faction.

\section{References}

Alexander, C. (2011). Architecture and the Secret of Immortality. Translation: Ghayoumi Bidhendi, Mehrdad, Third Edition, Tehran: Roozane Publishing..

Atkinson, A. B. (2005). The Atkinson review: final report. Measurement of government output and productivity for the national accounts. Palgrave Macmillan.

Barati, N., \& Soleimannejad, M. A. (2011). Perception of stimuli in controlled environment and gender impact on it (case study: faculty of architecture and urbanism students at the International University of Imam Khomaini, qazvin, Iran). 
Daneshgar Moghaddam, G., Bahraini, H., \& Einifar, A. (2011). An Investigation on sociability of the spaces based on perception of nature in the built environment, https://jfaup.ut.ac.ir/article_24682.html

Delak, H., Behzadfar, M., Ghale Noi, M., \& Bakhtiari Nasrabadi, A. (2017). Recognizing Behavioral Patterns in Isfahan Revolution Square. Environmental Studies of Haft Fence. http:/hafthesar.iauh.ac.ir/article-1-472-fa.html

Falamaki, M. M. (2015). Regeneration of Historical Buildings and Cities, First Edition, Tehran: Tehran University Publishing.

Holl, S., Pallasmaa, J., \& Gómez, A. P. (2006). Questions of perception: phenomenology of architecture. William K Stout Pub.

Kasmaee, M. (2003). Climate and architecture. Isfahan: Nashre khak.

Lang, J. (2002). Creation of architectural theory: the role of behavioral sciences in environmental design, translated by Alireza Einifar. University of Tehran publications institute.

Latifi, A., \& Sajjadzadeh, H. (2015). Evaluation of the effect of environmental quality components on behavioral patterns in urban parks, case study: Hamedan People's Park. Urban Studies, 3(11), 3-18.

Maier, J. R., \& Fadel, G. M. (2009). Affordance-based design methods for innovative design, redesign and reverse engineering. Research in Engineering Design, 20(4), 225.

Naghdbishi, R., Najafpour, H., \& Naghdbishi, E. (2019). Assessing the Quality of Architectural Training from the Perspective of the Instructors (Case Study: Faculty of Art and Architecture of Islamic Azad University of Roudehen Branch).

Palasma, J. (1992). The Thinker's Hand; The Wisdom of the Incarnate in Architecture. Translated by Ali Akbari, First Edition, Tehran: Parham Naqsh. p. 9

Riahi, V. (2002). Mazandaran, Second Edition, Tehran: Cultural Research Office.

Rivas, L.M. (2018). El lenguaje de patrones en los espacios abiertos: plazas de la parroquia Bolívar de Maracaibo, Revista de la Universidad del Zulia, 9 (23), 76-90.

Sadeghzadeh, M., \& Pourmohammadi, M. R. (2013). The Role of Behavioral Patterns in the Formation of Human-Oriented Urban Spaces from the Perspective of Christopher Alexander and Donald Appellard, National Conference on Humanitarian Architecture and Urban Planning, Qazvin, Islamic Azad University of Qazvin, https: // www. civilica.com/Paper-NCAUOl-NCAUOl_ll4.html

Shahcheraghi, A., \& Bandarabad, A. (2015). Inscription in the Environment; Application of Environmental Psychology in Architecture and Urban Planning, First Edition, Tehran: Jihad-e-Golestan University Publishing. 
REVISTA DE LA UNIVERSIDAD DEL ZULIA. $3^{a}$ época. Año 11 N 29, 2020

Zohreh Sanaei et al. /// Recognition of architectural patterns ...173-192

Shahrokhabadi, S., Vahedifard, F., Ghazanfari, E., \& Foroutan, M. (2019). Earth pressure profiles in unsaturated soils under transient flow. Engineering Geology, 260, 105218 .

Yin, B. (2003). Responsive Environments. Translated by Mostafa Behzadfar, Tehran, Iran University of Science and Technology. 